\title{
ANALISIS PERKEMBANGAN INDEKS HARGA KONSUMEN DI KOTA MEDAN
}

\section{ANALYSIS THE DEVELOPMENT OF CONSUMER PRICE INDEX IN MEDAN}

\author{
Sari Wulandari ${ }^{1}$, Muhammad Dani Habra ${ }^{2}$ \\ Universitas Muslim Nusantara Al Washliyah ${ }^{1,2}$ \\ sariwulandari@umnaw.ac.id ${ }^{1}$
}

\begin{abstract}
The Consumer Price Index (CPI) is one of the important economic indicators that can provide information about the development of prices of goods and services (commodities) paid by consumers or the public especially the city community. This study aims to analyze the Development of the Consumer Price Index in Medan City. The benefits of this research are a description of the fluctuations in commodity prices for basic needs of the community at the level of consumers or retail traders. This type of research is descriptive qualitative. The subject in this study is the Central Statistics Agency and the object in this study is the Consumer Price Index through seven groups of household expenditure in 2018-2019. The results showed that the development of price indices in Medan City tends to fluctuate from seven types of household expenditure groups. During the January-December 2019 period the highest inflation of the seven types of expenditure was foodstuffs.
\end{abstract}

Keywords: Consumer Price Index, Inflation Rate

\begin{abstract}
ABSTRAK
Indeks Harga Konsumen (IHK) merupakan salah satu indikator ekonomi penting yang dapat memberikan informasi mengenai perkembangan harga barang dan jasa (komoditas) yang dibayar oleh konsumen atau masyarakat khususnya masyarakat kotaPenelitian ini bertujuan untuk menganalisis Perkembangan Indeks Harga Konsumen di Kota Medan. Manfaat dari penelitian ini berupa gambaran mengenai fluktuasi harga komoditas kebutuhan pokok masyarakat di tingkat konsumen atau pedagang eceran. Jenis penelitian ini bersifat deskriptif kualitatif. Subjek dalam penelitian ini adalah Badan Pusat Statistik dan objek dalam penelitian ini adalah Indeks Harga Konsumen melalui tujuh kelompok pengeluaran rumah tangga tahun 2018-2019. Hasil Penelitian menunjukkan bahwa perkembangan indeks harga di Kota Medan cenderung berfluktuasi dari tujuh jenis kelompok pengeluaran rumah tangga. Selama Periode bulan Januari-Desember 2019 terlihat inflasi tertinggi dari tujuh jenis kelompok pengeluaran adalah bahan makanan.
\end{abstract}

Kata Kunci: Indeks Harga Konsumen, Laju Inflasi 


\section{PENDAHULUAN}

Situasi Ekonomi suatu Negara di pengaruhi oleh berbagai faktor diantaranya Inflasi, suku bunga, kebijakan-kebijakan pemerintah, isu-isu politik dan PDB (Produk Domestik Bruto). Inflasi dalam pengertiannya adalah kenaikan harga yang secara terus menerus yang mana inflasi tersebut salah satunya dipengaruhi oleh Indeks harga konsumen.

Indeks Harga Konsumen (IHK) merupakan salah satu indikator ekonomi penting yang dapat memberikan informasi mengenai perkembangan harga barang dan jasa (komoditas) yang dibayar oleh konsumen atau masyarakat khususnya masyarakat kota. Perubahan Indeks harga konsumen dari waktu ke waktu menunjukkan fluktuasi harga dari paket barang dan jasa yang dikonsumsi masyarakat, dimana dikatakan inflasi jika terjadi kenaikan dan dikatakan deflasi jika terjadi penurunan (Wanto \& Windarto, 2017). Dalam hal ini kota Medan merupakan salah satu kota terbesar di Sumatera Utara yang mana merupakan kota penggerak atas harga barang dan harga jasa tersebut. Terkait dengan hal diatas dibawah ini merupakan gambaran inflasi Provinsi Sumatera Utara selama tiga tahun terakhir:

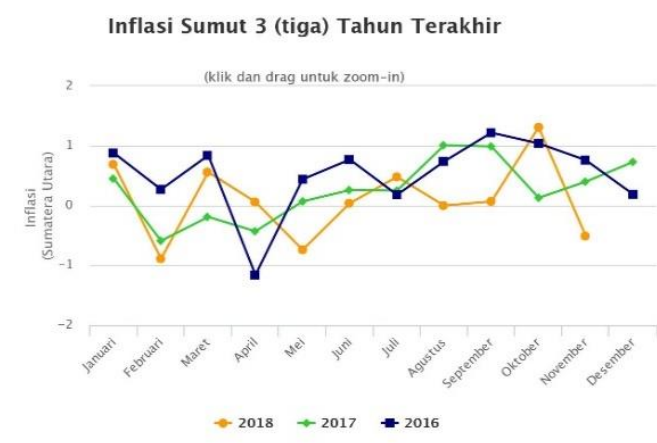

Sumber: BPS Sumut, 2019

Gambar 1. Inflasi Sumut 3 Tahun terakhir
Berdasarkan gambar diatas dapat terlihat bahwa inflasi di Provinsi Sumatera Utara selama 3 tahun terakhir mengalami fluktuasi. Dalam hal ini fluktuasi yang terjadi pada tingkat inflasi salah satu faktor yang mendominasi adalah indeks harga konsumen di Kota Medan.

Harga dapat diartikan sebagai jumlah uang (atau alat tukar lain) yang harus dibayarkan untuk produk ataupun jasa. Harga juga dapat berarti nilai dari sebuah barang ataupun jasa. Ketika kita mengunjungi sebuah toko pasti setiap barang yang dijual memiliki harga masing-masing. Namun, harga tersebut pastinya tidak selalu sama dari waktu ke waktu (Lux viantono et al., 2018). Harga konsumen merupakan harga transaksi yang terjadi antara pedagang/pengecer dengan pembeli/konsumen atas suatu barang dan jasa dengan tujuan untuk dikonsumsi.

Dalam pencatatan harga, berbagai hal yang perlu dipahami antara lain sebagai berikut : Barang dan jasa yang diamati adalah barang dan jasa yang merupakan barang akhir (final goods), artinya benar-benar dibeli untuk dikonsumsi (Husnul et al., 2017). Kualitas, merk dagang adalah kualitas/merk yang paling banyak dikonsumsi oleh masyarakat setempat, dan diusahakan tidak berubah-ubah, Satuan, kemasan diusahakan satuan/kemasan yang lazim di wilayah tersebut, untuk itu diperlukan kehatihatian dalam melakukan konversi bilamana terjadi ketidaksamaan satuan, Harga yang terjadi /dicatat termasuk pajak tak langsung misalnya PPN, cukai dan sebagainya, Pencatatan harga dilaksanakan pada saat pasar sedang ramai-ramainya pembeli (peak hour), Harga yang dicatat adalah harga tunai (cash), Pedagang/penjual harus pedagang eceran dengan persediaan barang yang relatif banyak, ramai 
dikujungi pembeli dan harganya merupakan price leader.

Pasar merupakan tempat terjadinya transaksi atas sesuatu barang dan jasa yang dihasilkan antara penjual dan pembeli (Wanto \& Windarto, 2017). Secara teoritis harga konsumen harus lebih tinggi daripada harga pedagang besar maupun produsen. Pasar yang dimaksudkan untuk pencatatan harga konsumen adalah pasar konsumsi. Untuk menentukan pasar sebagai objek survei perlulah mengamati hal-hal sebagai berikut: Pasar yang dipilih adalah pasar yang paling banyak dikunjungi konsumen/pasar yang paling besar, Komoditas barang dalam pasar tersebut relatif banyak dan lengkap, Pengunjung pasar/konsumen mewakili sebagian besar masyarakat setempat, Harga-harga barang dan jasa di pasar tersebut merupakan pantauan bagi pasar-pasar lainnya/disekitarnya, Diusahakan pasarnya bukan pasar musiman, tetapi yang ramai setiap hari.

Harga barang atau jasa " $A$ " pada hari ini belum tentu sama dengan harga di masa depan ataupun masa lalu. Perubahan-perubahan harga ini kemudian dicatat serta dihitung rataratanya dan disebut sebagai Indeks Harga. Indeks harga nantinya digunakan sebagai sebuah alat ukur serta petunjuk bagi perekonomian negara. Pencatatan data dari Indeks harga di Indonesia sendiri dilakukan oleh Badan Pusat Statistik atau BPS.

Tujuan Penghitungan Indeks Harga diantaranya: Petunjuk dalam pengambilan keputusan serta kebijakan baik oleh pelaku usaha maupun pemerintah, Sebagai alat ukur dalam melihat dan mengukur tingkat ekonomi pada satu masa ke masa lain, Mengukur tingkat inflasi sebuah Negara (Lubis et al., 2017).
Indeks Harga Konsumen adalah suatu indeks yang menghitung rata-rata perubahan harga dalam suatu periode, dari suatu kumpulan harga barang dan jasa yang dikonsumsi oleh penduduk rumah tangga dalam kurun waktu tertentu. Angka tahun dasar adalah angka nilai konsumsi rumah tangga (dari hasil survei) yang menjadi patokan/dasar untuk dibandingkan dengan angka-angka selanjutnya, lazimnya angka tahun dasar dibuat 100.

Bilamana angka indeks suatu periode lebih besar dari 100, dapat diartikan terjadi kenaikan harga/inflasi, sebaliknya bilamana angka pada suatu periode lebih kecil dari 100 dapat diartikan terjadi deflasi.

Jenis barang dan jasa tersebut dikelompokkan menjadi 7 kelompok yaitu bahan makanan; makanan jadi, minuman, rokok dan tembakau; perumahan, air, listrik, gas dan bahan bakar; Sandang; Kesehatan; Pendidikan, rekreasi dan olah raga; transpor, komunikasi, dan jasa keuangan.

Beberapa penelitian terdahulu telah mengkaji keterkaitan indeks harga konsumen terhadap laju inflasi siantaranya penelitian oleh Kristianie (2018) meneliti tentang pengaruh indeks harga konsumen terhadap inflasi dengan menggunakan pendekatan asosiatif dimana diperoleh bahwa IHK berpengaruh signifikan terhadap laju inflasi. Sedangkan penelitian Karlina (2017) menitikberatkan kepada pentingnya inflasi terhadap GDP di Indonesia dimana hasil penelitiannya menunjukkan bahwa perubahan Produk Domestik Bruto (PDB) di Indonesia dari tahun 2011 - 2015 dipengaruhi oleh indeks harga dan tingkat inflasi dan tidak pada IHK.

\section{METODE PENELITIAN}

Metode yang digunakan dalam penelitian ini adalah deskriptif 
kualitatif. sebagai metode penelitian yang berlandaskan pada filsafat postpositivisme, digunakan untuk meneliti pada kondisi objek alamiah, dimana peneliti adalah sebagai instrumen kunci, teknik pengumpulan data dengan triangulasi, analisis data bersifat induktif atau kualitatif, dan hasil penelitian kualitatif lebih menekankan makna daripada generalisasi, serta teknik pengumpulan data dengan dokumentasi. Data yang dikumpulkan dalam penelitian ini diperoleh dari sumber data sekunder melalui Badan Pusat Statitsik (BPS) Kota Medan.

\section{HASIL DAN PEMBAHASAN}

Dari hasil penelitian terlihat bahwa selama periode JanuariDesember 2019, tingkat inflasi tertinggi di Kota Medan terjadi pada bulan Juni 2019 sebesar 1,68 persen, diikuti bulan mei 2019 sebesar 1,33 persen dan bulan maret sebesar 1,30 persen. Tingginya tingkat inflasi di bulan Juni 2019 dipengaruhi oleh kenaikan indeks harga kelompok pengeluaran terutama bahan makanan (6,39 persen). selama periode tersebut, terjadi deflasi di bulan september (1,92 persen), November ( 0,77 persen $)$, februari $(0,30$ persen $)$ dan desember ( 0,28 persen).

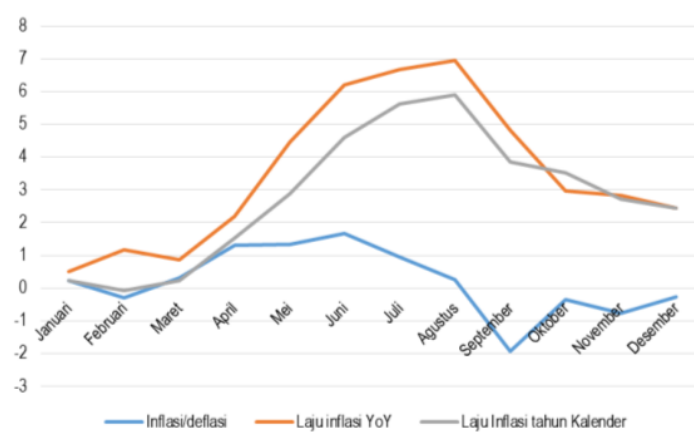

Sumber : BPS Kota Medan (2019)

$\begin{array}{cl}\text { Gambar } & \begin{array}{l}\text { 2.Perkembangan Inflasi/Deflasi } \\ \text { Kota Medan Januari-Desember } \\ 2019\end{array}\end{array}$
Perkembangan inflasi tertinggi untuk kelompok bahan makanan terjadi pada bulan Juni 2019 mencapai 6,39 persen, diikuti bulan April 4,94 persen, bulan Mei 4,79 persen, bulan Juli 3,29 persen, bulan Maret 1,67 persen dan bulan Agustus 1,09 persen. Tingginya inflasi pada periode tersebut terutama dipengaruhi oleh meningkatnya indeks harga sub kelompok sayur-sayuran dan sub kelompok daging.

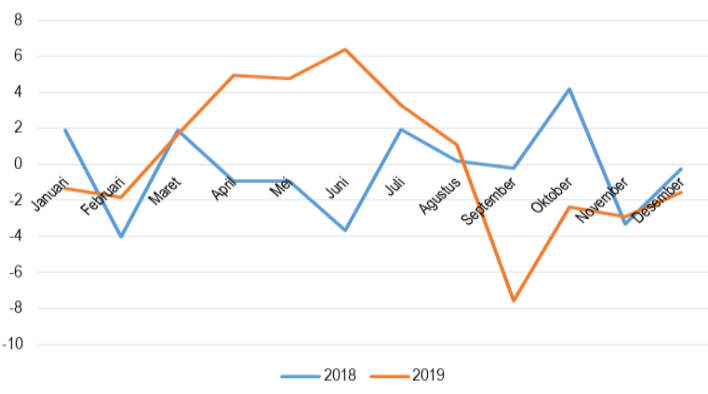

Sumber : BPS Kota Medan (2019)

Gambar 3. Perkembangan Inflasi/Deflasi Bulanan Kelompok Makanan, 2018-2019

Selama bulan Januari-Desember 2019 laju inflasi kelompok makanan jadi, minuman, rokok, dan tembakau lebih tinggi dari dibandingkan laju inflasi yang terjadi selama tahun 2018 . Indeks harga tertinggi di tahun 2019 terjadi pada bulan Oktober sebesar 1,35 persen. Sedangkan pada tahun 2018 kenaikan indeks harga tertinggi terjadi pada bulan September 0,78 persen.

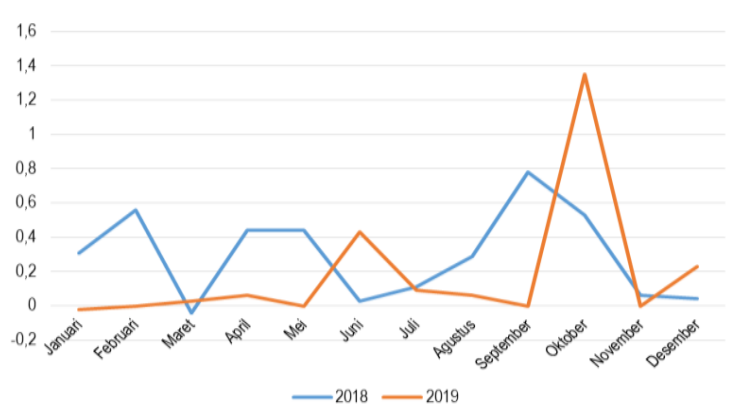

Sumber : BPS Kota Medan (2019)

Gambar 4. Perkembangan Inflasi/Deflasi Bulanan Kelompok Makanan Jadi, Minuman, Rokok, dan Tembakau, 2018-2019 
Laju inflasi tertinggi selama bulan Januari-Desember 2019 terjadi pada bulan September 2019 yaitu mencapai 0,47 persen diikuti bulan Juni 2019 sebesar 0,23 persen dan bulan Mei 2019 sebesar 0,22 persen. Naiknya indeks harga pada bulan September 2019 dipengaruhi oleh perubahan harga komoditas sewa rumah, batu bata/batu tela, setrika, sabun/detergen bubuk/cair, sabun cair/cuci piring dan penyegar ruangan.

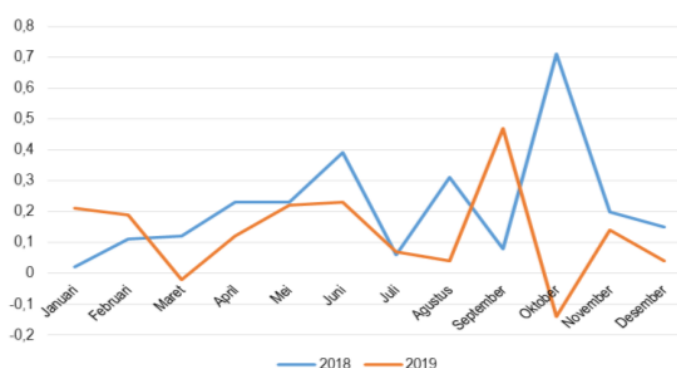

Sumber : BPS Kota Medan (2019)

Gambar 5. Perkembangan Inflasi/Deflasi Bulanan Kelompok Perumahan, air, listrik, gas dan bahan bakar, 2018-2019

Kenaikan indeks harga kelompok sandang selama JanuariDesember 2019 tercatat sebesar 5,36 persen. Kenaikan indeks harga terjadi pada bulan Juli 2019 yang mencapai 1,23 persen. Tingginya kenaikan indeks tersebut terutama disebabkan oleh meningkatnya sub kelompok sandang laki-laki dewasa yang mengalami kenaikan indeks harga sebesar 2,48 persen.



Sumber : BPS Kota Medan (2019)

Gambar 6. Perkembangan Inflasi/Deflasi Bulanan Kelompok Makanan, 2018-2019
Perkembangan indeks harga kelompok kesehatan selama bulan Januari-Desember 2019 terjadi pada bulan Februari 2019 sebesar 1,17 persen, diikuti bulan Maret sebesar 0,41 persen dan bulan April sebesar 0,23 persen.



Sumber : BPS Kota Medan (2019)

\section{Gambar 7. Perkembangan Inflasi/Deflasi Bulanan Kesehatan, 2018-2019}

Laju inflasi kelompok pendidikan, rekreasi dan olahraga selama bulan Januari-Desember 2019 tercatat sebesar 1,44 persen, lebih tinggi dibandingkan dengan tahun 2018 sebesar 1,23 persen. Inflasi tersebut terjadi pada bulan Februari, Juli dan Agustus. Hal tersebut terjadi dikarenakan terjadinya kenaikan pada sub kelompok biaya pendidikan.

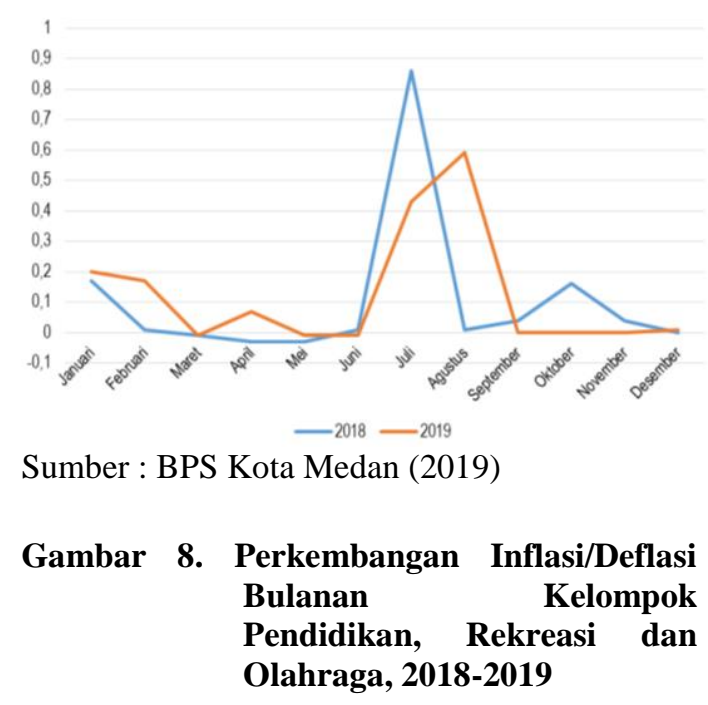


Selama periode bulan JanuariNovember 2019, kelompok transportasi, komunikasi dan jasa keuangan mengalami inflasi tertinggi terjadi pada bulan Januari 2019 sebesar 2,13 persen diikuti bulan Agustus 2019 sebesar 0,55 persen dan bulan Desember 2019 sebesar 0,48 persen. Tingginya inflasi di bulan Januari 2019 dipengaruhi oleh kenaikan harga sub kelompok transportasi.

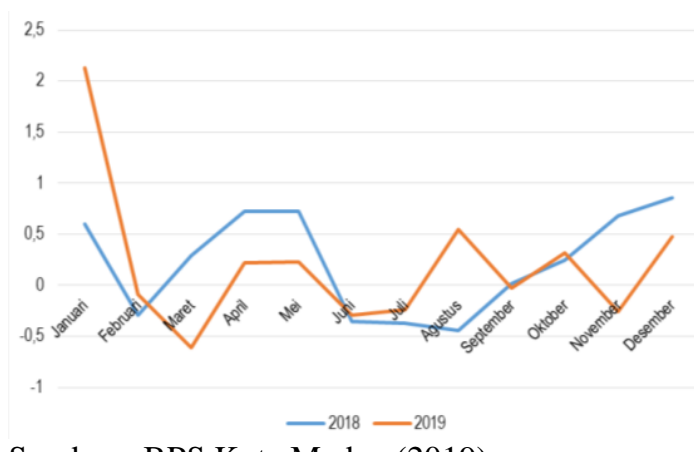

Sumber : BPS Kota Medan (2019)

Gambar 9. Perkembangan Inflasi/Deflasi Bulanan Kelompok Transportasi, Komunikasi dan Jasa Keuangan, 20182019

Dari hasil analisa pada tujuh jenis kelompok pengeluaran rumah tangga terlihat bahwa kelompok bahan makanan sebesar 6,39 persen pada bulan Juni 2019; kelompok makanan Jadi, minuman, rokok dan tembakau tertinggi sebesar 1,35 persen pada bulan oktober 2019; kelompok perumahan, air, listrik, gas dan bahan bakar sebesar 0,47 persen pada bulan september 2019; kelompok sandang sebesar 1,23 persen pada bulan juli 2019; kelompok kesehatan 1,17 persen pada bulan februari 2019; kelompok pendidikan, rekreasi dan olahraga sebesar 0,59 persen pada bulan agustus 2019; dan kelompok transportasi, komunikasi dan jasa keuangan sebesar 2,13 persen pada bulan Januari 2019.

Hasil penelitian ini konsisten dengan penelitian Suarsih (2016), serta
Wanto \& Widarto (2017) bahwa untuk menekan laju inflasi harus dilakukan analisis pada Indeks harga konsumen sehingga dapat diketahui komoditas mana yang perlu mendapatkan perhatian. Daya beli masyarakat juga harus dipantau secara berkala sehingga permintaan pasar pada tingkat konsumen dan pedagang eceran terus mengalami peningkatan (Husnul, 2017).

\section{PENUTUP}

Kesimpulan

Dari Hasil dan pembahasan maka dapat ditarik kesimpulan bahwa perkembangan indeks harga Konsumen di Kota Medan cenderung berfluktuasi dari tujuh jenis kelompok pengeluaran rumah tangga. Selama Periode bulan Januari-Desember 2019 terlihat inflasi tertinggi dari tujuh jenis kelompok pengeluaran adalah bahan makanan.

\section{Saran}

berikan $\begin{gathered}\text { Saran yang dapat penulis } \\ \text { untuk penelitian ini }\end{gathered}$ diantaranya:

1.Penelitian lanjutan disarankan lebih memperbanyak pencarian data dan menganalisa lebih konkrit.

2. Penelitian lanjutan diharapkan menambah variabel lain sehingga pengaruh dapat terlihat.

\section{DAFTAR PUSTAKA}

BPS Kota Medan, (2019), Berita Resmi Statistik Perkembangan Indeks Harga Konsumen Bulan Desember $2019 \quad$ No. 01/01/1275/Th.XI, 3 Januari 2020", Medan.

Husnul, H. M., Hidayat, R. R., \& Sulasmiyati, S. (2017). Analisis Pengaruh Inflasi, Kurs (Idr/Usd), Produk Domestik Bruto Dan Harga Emas Dunia Terhadap Indeks Harga Saham Gabungan (Studi Pada Indonesia Periode 
2008-2016). Jurnal Administrasi Bisnis, 53(1), 66-74.

Karlina, B. (2017). Pengaruh Tingkat Inflasi, Indeks Harga Konsumen Terhadap PDB di Indonesia Pada Tahun 2011-2015. Jurnal Ekonomika dan Manajemen, 6(1), 16-27.

Kristinae, V. (2018). Analisis Pengaruh Indeks Harga Konsumen Terhadap Inflasi. Jurnal Aplikasi Manajemen, Ekonomi dan Bisnis, 3(1), 1-11.

Luxviantono, E., Setiawan, A., \& Sasongko, L. R. (2018). Analisis Hubungan IHK (Indeks Harga Konsumen) dan Kurs Beli IDRUSD Melalui Pendekatan Copula. d'CARTESIAN, 7(2), 52-58.

Lubis, D. A., Johra, M. B., \& Darmawan, G. (2017). Peramalan Indeks Harga Konsumen dengan Metode Singular Spectral Analysis (SSA) dan Seasonal Autoregressive Integrated Moving Average (SARIMA). $J$. Mat. MANTIK, 3(2), 74-82.

Suarsih, S., Achsani, N. A., \& Nuryartono, N. (2016). Dampak Perubahan Nilai Tukar Terhadap Indeks Harga Konsumen Bahan Makanan di Indonesia. Jurnal Ekonomi dan Pembangunan Indonesia, 17(1), 1-14.

Wanto, A., \& Windarto, A. P. (2017). Analisis Prediksi Indeks Harga Konsumen Berdasarkan Kelompok Kesehatan Dengan Menggunakan Metode Backpropagation. SinkrOn, 2(2), 37-4 